\title{
IDENTIFICATION AND PROPERTIES OF TWO EXTRACELLULAR PROTEASES FROM BREVUNDIMONAS DIMINUTA
}

\author{
André Adriano Chaia ${ }^{1}$; Salvatore Giovanni-De-Simone ${ }^{2,3}$; Simone Dias Gonçalves Petinate ${ }^{1}$; Ana Paula Cabral de \\ Araújo Lima ${ }^{4}$; Marta Helena Branquinha ${ }^{1}$; Alane Beatriz Vermelho ${ }^{1^{*}}$
}

${ }^{1}$ Departamento de Microbiologia Geral, Instituto de Microbiologia Professor Paulo de Góes, Universidade Federal do Rio de Janeiro, Rio de Janeiro, RJ, Brasil. ${ }^{2}$ Departamento de Bioquímica e Biologia Molecular, FIOCRUZ, Rio de Janeiro, RJ, Brasil. ${ }^{3}$ Departamento de Biologia Celular e Molecular, Instituto de Biologia, Universidade Federal Fluminense, Rio de Janeiro, RJ, Brasil. ${ }^{4}$ Instituto de Biofísica Carlos Chagas Filho, Universidade Federal do Rio de Janeiro, Rio de Janeiro, RJ, Brasil

Submited: March 14, 1998; Returned to authors for corrections: March 25, 1999; Approved: January 16, 2000

\begin{abstract}
Extracellular proteases from Brevundimonas diminuta (syn. Pseudomonas diminuta) were studied in sodium dodecyl sulfate polyacrylamide gel electrophoresis (SDS-PAGE) containing a copolymerized substrate. Two proteases were detected migrating at $67 \mathrm{kDa}$ and $50 \mathrm{kDa}$ : both of them hydrolysed preferentially gelatin, but casein was also degraded and a slight hydrolysis was observed with hemoglobin. No detectable extracellular proteolytic activity was found in bovine serum albumin-containing gels. The optima temperature and $\mathrm{pH}$ for proteolytic activity were between $40^{\circ} \mathrm{C}$ and $50^{\circ} \mathrm{C}$ in a $\mathrm{pH}$ ranging from 7.0 to 11.0 , respectively. These enzymes were isolated by analytical high performance liquid chromatography (HPLC). Protease assays with the synthetic substrate Z-Phe-Arg-MCA and the inhibitors EGTA, EDTA and 1, 10 phenanthroline point out that these enzymes are metalloproteases.
\end{abstract}

Key words : metalloproteases, Brevundimonas diminuta, Pseudomonadaceae, extracellular proteases

\section{INTRODUCTION}

Brevundimonas diminuta is the new nomenclature for former Pseudomonas diminuta based on a new genus name, proposed for the species of Pseudomonadaceae family rRNA group IV, often referred to as the diminuta group. Members of the genus Brevundimonas are found in water and differ from the authentic pseudomonads by having short wavelenght polar flagella, restricted biochemical activity, different polyamine and ubiquinone patterns as well as different fatty acid composition (15).

B. diminuta has been a target of several biochemical studies due to a zinc-dependent phosphotriesterase which catalyses the hydrolysis of several toxic organophosphates triesters (5). The catalytic role of zinc is similar to the mechanisms proposed for many metalloenzymes including proteases such as carboxypeptidases and thermolysin (6). This group of bacterium is also able to degrade aerobically isoquinoline, a toxic compound used in pesticides, medicaments, antioxidants and corrosion inhibitors (14). As in the family Pseudomonadaceae several species produce metallo and serine proteases $(2,9,13$, 16) and because there is no information about the type and function of these enzymes in $B$. diminuta, it was decided to study the occurrence and type of secreted proteases from this microrganism.

\section{MATERIALS AND METHODS}

Bacterial strain and growth conditions. Brevundimonas diminuta ATCC 11568 was grown in meat extract medium containing $4 \mathrm{~g} / 1$ meat extract, $10 \mathrm{~g} / 1$ peptone and $5 \mathrm{~g} / 1 \mathrm{NaCl}$ for 10 days at $28^{\circ} \mathrm{C}$. The cultures were not shaken.

\footnotetext{
* Corresponding author. Mailing address: Departamento de Microbiologia Geral, Instituto de Microbiologia Prof. Paulo de Goés, UFRJ, CCS, B1. I, CEP 21949900, Rio de Janeiro, RJ, Brasil. Fax: (+5521) 5608344. E-mail: immgbia@microbio.ufrj.br
} 
Preparation of cellular extracts and extracellular concentrates. $1.2 \times 10^{9}$ cells were processed as previously described (4). For protease secretion studies, $30 \mathrm{ml}$ daily aliquots of culture medium were collected during 10 days and concentrated by dialysis against polyethyleneglycol overnight at $4^{\circ} \mathrm{C}$. For substrate-containing SDS-PAGE, the extracellular concentrate was mixed with sample buffer $(0.125 \mathrm{mM}$ Tris- $\mathrm{HCl}$, pH 6.8, 4\% SDS, $20 \%$ glycerol and $2 \%$ bromophenol blue) in a proportion of $7: 3(\mathrm{v} / \mathrm{v})$.

Substrate-containing SDS-PAGE. Proteases in cellular and extracellular extracts ( $100 \mu \mathrm{g}$ of protein, according to Lowry et al. (11) method) were assayed and characterized by electrophoresis in $7.5 \%$ SDS-PAGE (10) with $0.1 \%$ copolymerized substrate (7). Gelatin, casein, hemoglobin and bovine serum albumin (BSA) were used as substrates. Following electrophoresis, gels were incubated for $24 \mathrm{~h}$ at $37^{\circ} \mathrm{C}$ under two different conditions: $50 \mathrm{mM}$ phosphate buffer at $\mathrm{pH} 5.5$, or 100 $\mathrm{mM}$ glycine-NaOH buffer at $\mathrm{pH} 10.0$. To detect the presence of proteases, gels were stained with $0.1 \%$ amido black in methanolacetic acid-water $(3: 1: 6)$ and destained with water until the appearance of clear zones.

Effect of temperature and $\mathrm{pH}$ on proteolytic activity. Substrate hydrolysis on SDS-PAGE-gelatin was assayed at different temperatures $\left(28^{\circ} \mathrm{C}, 40^{\circ} \mathrm{C}, 50^{\circ} \mathrm{C}, 60^{\circ} \mathrm{C}\right.$ and $\left.70^{\circ} \mathrm{C}\right)$ for $24 \mathrm{~h}$ at $\mathrm{pH}$ 10.0. The effect of $\mathrm{pH}$ was determined with the following buffers: $200 \mathrm{mM}$ acetate (pH 4.0 and 5.0); $200 \mathrm{mM}$ phosphate ( $\mathrm{pH} 6.0$ to 8.0$) ; 200 \mathrm{mM}$ carbonate-bicarbonate $(\mathrm{pH}$ 9.0 and 10.0); and $100 \mathrm{mM}$ glycine- $\mathrm{NaOH}$ (pH 11.0 and 12.0). The assays for optimal $\mathrm{pH}$ were carried out at $37^{\circ} \mathrm{C}$ for $24 \mathrm{~h}$.

Gel-filtration high performance liquid chromatography (HPLC). The cell-free culture supernatant $(1 \mathrm{~L})$ was concentrated and injected in a Shinpack Diol-150 (50 cm x 7.9 $\mathrm{cm}$, I.D.) HPLC column (Shimadzu, Kyoto, Japan) previously equilibrated in $50 \mathrm{mM}$ phosphate buffer ( $\mathrm{pH}$ 7.2). The proteins were fractionated on an automatic HPLC system (Shimadzu, $6 \mathrm{~A}$ model) at a flow-rate of $1 \mathrm{ml} / \mathrm{min}$, for $30 \mathrm{~min}$ at $25^{\circ} \mathrm{C}$. For molecular mass determination the column was calibrated with the same buffer with the following markers: $\beta$-galactosidase $(\mathrm{Mr}$ $105 \mathrm{kDa}$ ), bovine serum albumin (BSA, Mr $66 \mathrm{kDa}$ ), ovalbumin (Mr $45 \mathrm{kDa}$ ) and carbonic anhydrase (Mr $29 \mathrm{kDa})$. Protein determinations were made by the method of Lowry et al. (11), with bovine serum albumin as a standard.

Detection of proteolytic activity using fluorogenic substrate. Proteolytic activity was determined by measuring the rate of hydrolysis in fluorimetric continuous assays. The release of product was observed in $100 \mathrm{mM}$ glycine- $\mathrm{NaOH}$ buffer, $\mathrm{pH} 10.0$, containing $0.12 \mu \mathrm{g}$ of purified proteases and $10 \mu \mathrm{M}$ Z-Phe-Arg-MCA (Sigma Chem. Co., St. Louis, MO) as substrate, using a F-4500 fluorescence spectrophotometer (Hitachi, Japan). Table 1 shows the proteolytic inhibitors used.

\section{RESULTS}

B. diminuta proteases hydrolysed preferentially gelatin, however distinct profiles were obtained for cellular and extracellular proteases (Fig. 1). A $80 \mathrm{kDa}$ band was only detected in cellular extracts, while $67 \mathrm{kDa}$ and $50 \mathrm{kDa}$ proteases were observed in both extracts. A $67 \mathrm{kDa}$ protease was found in $B$. diminuta cells and was released to culture medium, being able to hydrolyse casein, gelatin and hemoglobin. No detectable extracellular proteolytic activity was found in BSA-containing gels. However, in cellular extracts, a slight hydrolysis was observed at $\mathrm{pH} 5.5$, for the $80 \mathrm{kDa}$ protease (Fig. 1). Extracellular proteases yield low proteolytic activity in hemoglobin-containing gels, and only at $\mathrm{pH} 5.5$ (Fig. 1). This activity was more proeminent in cellular proteases.

Protease secretion studies showed that only the $67 \mathrm{kDa}$ protease was released to culture medium during the first five days of culture (Fig. 2). After 6 days of cultivation, the $50 \mathrm{kDa}$ enzyme was also detected (Fig. 2). No qualitative differences were observed until the tenth day.

Fig. 3 shows the extracellular proteases $\mathrm{pH}$ activity profile. The optimum $\mathrm{pH}$ for extracellular proteases activity was found in a 7.0 to $11.0 \mathrm{pH}$ range. Low activity was found below $\mathrm{pH}$ 7.0. The effect of temperature on the activity of these enzymes was determined incubating the gels at various temperatures. The optimum temperature for extracellular proteolytic activity was between $40^{\circ} \mathrm{C}$ and $50^{\circ} \mathrm{C}$ (Fig. 4).

Table 1. Effect of protease inhibitors on Brevundimonas diminuta extracellular proteolytic activity.

\begin{tabular}{cccc}
\hline Inhibitors & $\begin{array}{c}\text { Concentration } \\
(\mathrm{mM})\end{array}$ & \multicolumn{2}{c}{ Relative Activity (\%) } \\
\cline { 3 - 4 } & & Fraction A & Fraction B \\
\hline Control & & 100 & 100 \\
Aprotinin & $3.08 \times 10^{-7}$ & 90 & 100 \\
PMSF & 1 & 128 & 119 \\
E-64 & 0.01 & 98 & 84 \\
Iodoacetamide & 0.1 & 107 & 103 \\
Pepstatin A & 1 & 95 & 101 \\
EDTA & 100 & 117 & 75 \\
EGTA & 100 & 42 & 15 \\
1.10 Phenanthroline & 30 & 12 & 8 \\
\hline
\end{tabular}

By passing the extracellular concentrates through the gel filtration column, three fractions were obtained (not shown). These fractions were collected according to the molecular masses previously determined for the extracellular proteases on SDSPAGE-gelatin: Fraction A (corresponding to $64-68 \mathrm{kDa}$ ), Fraction 
$C_{E}$

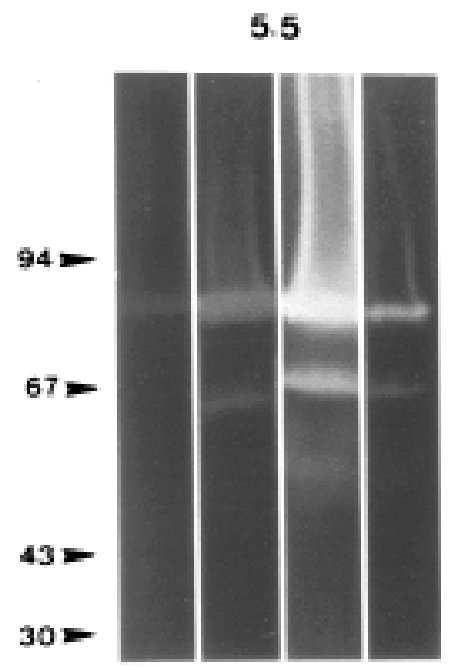

B
10.0

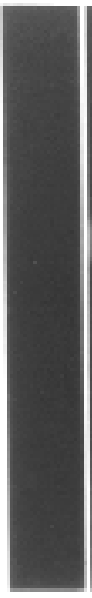

B

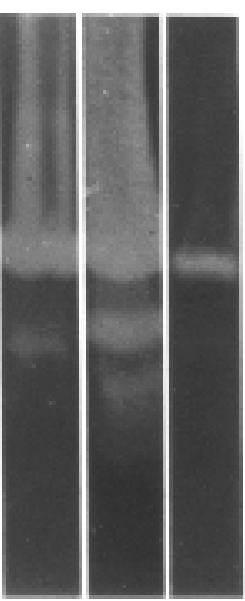

H
E
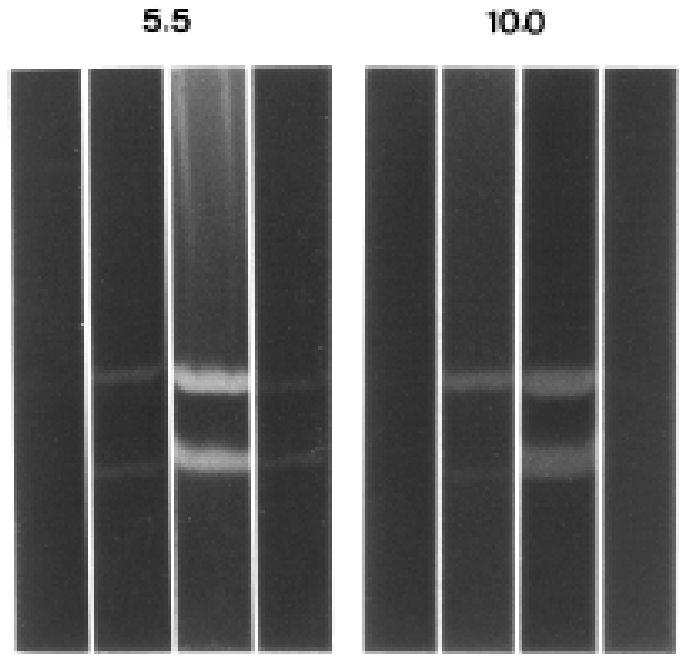

B $C$ G
B C G H

Figure 1. Detection of Brevundimonas diminuta proteolytic activities on BSA (B), casein $(\mathrm{C})$, gelatin $(\mathrm{G})$ and hemoglobin $(\mathrm{H})$ containing gels. Ce, cellular and $\mathrm{E}$, extracellular proteases. Gels were incubated at $\mathrm{pH} 5.5$ and at $\mathrm{pH}$ 10.0. Numbers on the left refer to the position of molecular weight markers (in $\mathrm{kDa}$ ).

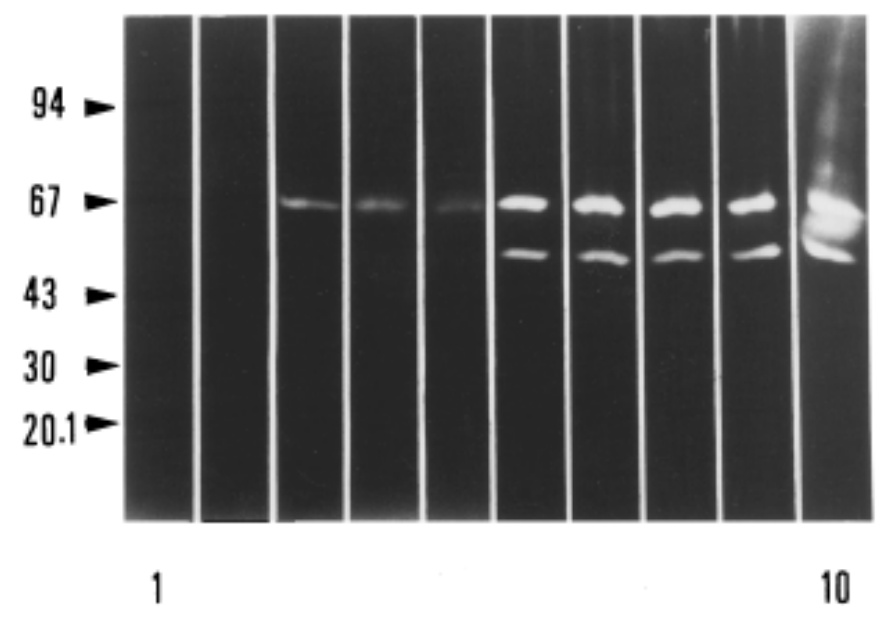

Figure 2. Secretion of proteases during Brevundimonas diminuta growth. Aliquots of the culture medium were collected from the first (1) to the tenth (10) day of culture and analysed on SDS-PAGE-gelatin.

B (50-52 kDa) and Fraction C (below $30 \mathrm{kDa})$. This procedure resulted in partial purification of the enzyme activities in fractions $\mathrm{A}$ and $\mathrm{B}$, as demonstrated by SDS-PAGE-gelatin. The fractions $\mathrm{A}, \mathrm{B}$ and $\mathrm{C}$ obtained from $2.3 \mathrm{mg}$ of protein yielded $0.29,0.32$ and $1.68 \mathrm{mg}$ of proteins with a percentage recovery of $12.8,14.2$ and $73 \%$ (related to the HPLC column), respectively.

The inhibition profile of the extracellular proteases (obtained

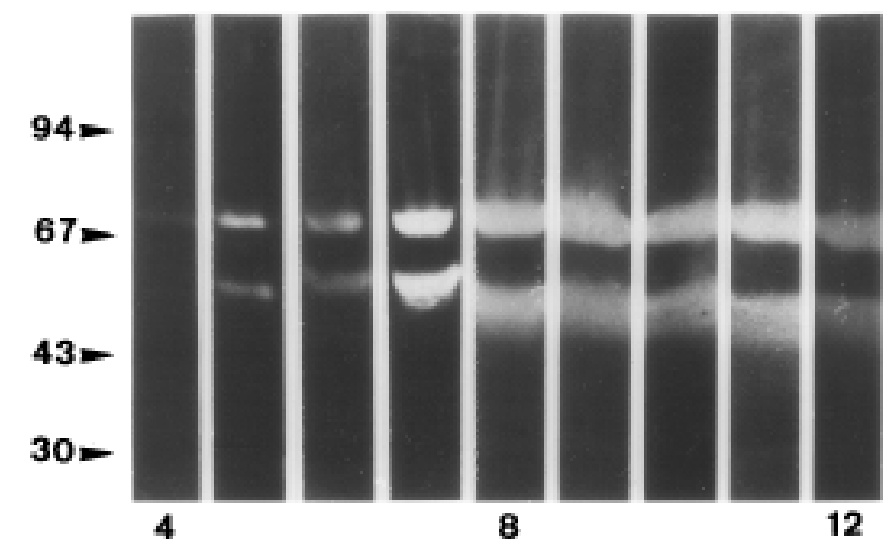

Figure 3. Effect of $\mathrm{pH}$ on Brevundimonas diminuta extracellular proteolytic activities. Extracts were analysed on SDS-PAGE-gelatin in a 4.0 to $12.0 \mathrm{pH}$ range.

in Fractions A and B, respectively) with various protease inhibitors is shown in Table 1. Inhibitors to cysteine-proteases (E-64, iodoacetamide), serine proteases (PMSF, aprotinin) and aspartic proteases (pepstatin A) failed to inhibit the enzymes. The proteases were inhibited by typical metal chelators such as EGTA and 1,10-phenanthroline, which indicates that both enzymes are metalloproteases. 


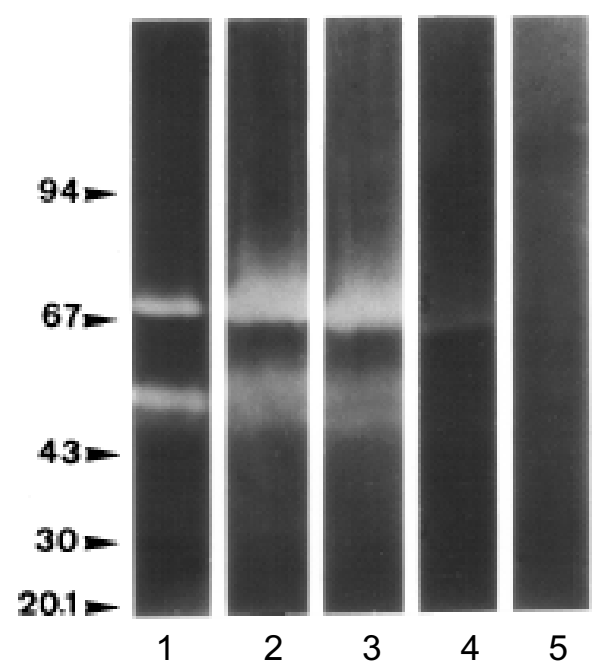

Figure 4. Effect of temperature on Brevundimonas diminuta extracellular proteolytic activities. Extracts were analysed on SDS-PAGE-gelatin at $28^{\circ} \mathrm{C}$ (1), $40^{\circ} \mathrm{C}(2), 50^{\circ} \mathrm{C}(3), 60^{\circ} \mathrm{C}(4)$ and $70^{\circ} \mathrm{C}(5)$.

\section{DISCUSSION}

While there have been several metallo and serine-proteases reported in the literature in the Pseudomonadaceae family, the detection of proteases in $B$. diminuta has never been described $(2,9,13,16)$.

The present study indicates that Brevundimonas diminuta, a member of the Pseudomonadaceae family, is able to release into the culture medium two metalloproteases with molecular masses of $50 \mathrm{kDa}$ and $67 \mathrm{kDa}$. By means of a SDS-PAGE-gelatin analysis, cell-associated proteases of $50 \mathrm{kDa}, 67 \mathrm{kDa}$ and 80 $\mathrm{kDa}$ were detected. Our findings point to the possibility that the $50 \mathrm{kDa}$ cellular and extracellular proteases are different enzymes. The cell-associated enzyme hydrolysed gelatin only, but the extracellular one also displayed proteolytic activity with casein and hemoglobin at $\mathrm{pH} 5.5$ and 10.0. The $67 \mathrm{kDa}$ protease showed the same pattern of degradation of substrates, being able to hydrolyse casein, gelatin and hemoglobin, and probably being released to culture medium. These extracellular enzymes typically have low substrate specificity and function in the degradation of exogenous proteins for assimilation into the catabolic pathways, differing from intracellular proteases that have high substrate specificities and are associated with metabolic regulation mechanisms such as protein turnover and modification of regulatory enzymes (3). In addition, extracellular metalloproteases have been shown to contribute to the bacterial pathogenesis of $P$. aeruginosa (8).

In the growth conditions employed in this study, the proteases were secreted following a $72 \mathrm{~h}$ interval. The production of these enzymes is heterogenous in Pseudomonas spp. It has been described that distinct amounts of enzymes are detected in different strains of $P$. aeruginosa (12).

The effect of metal chelators on $B$. diminuta extracellular proteolytic activity suggests that these enzymes are calciumactivated zinc-metalloproteases. The loss of activity in the presence of EGTA, which has affinity for calcium, is probably due to the capture of $\mathrm{Ca}^{+2}$ ions that are critical to the tertiary structure of the protein, resulting in an enzyme more susceptible to autoproteolysis and to difficulties in refolding. Previous reports showed that $P$. aeruginosa alkaline protease contains one $\mathrm{Zn}^{+2}$ atom in the catalytic center and requires several $\mathrm{Ca}^{+2}$ ions for stabilization of its folding (13).

Studies with $B$. diminuta are interesting since this microorganism was already isolated from clinical specimens, sewage and soil (1). As far as we can ascertain from the literature, this is the first example of proteolytic activity described in $B$. diminuta. The extracellular metalloproteases described in this work are probably involved in the nutrition and/or in the decomposition of organic matter in soil.

\section{ACKNOWLEDGMENTS}

This work was supported by CNPq, CEPG/UFRJ, FINEPBID, FAPERJ and FUJB.

\section{RESUMO}

\section{Identificação e propriedades de duas proteases extracelulares de Brevundimonas diminuta}

Proteases extracelulares de Brevundimonas diminuta (Pseudomonas diminuta) foram identificadas e caracterizadas por eletroforese em gel de poliacrilamida com dodecilsulfato de sódio, contendo um substrato co-polimerizado. Duas proteases foram detectadas migrando em $67 \mathrm{kDa}$ e $50 \mathrm{kDa}$ : ambas hidrolisaram preferencialmente a gelatina, embora a caseína também tenha sido degradada e uma pequena hidrólise tenha sido observada com hemoglobina. Nenhuma atividade proteolítica extracelular foi detectada nos géis contendo soro albumina bovina. Condições ótimas de temperatura e $\mathrm{pH}$ para a atividade proteolítica foram observadas entre $40^{\circ} \mathrm{C}$ e $50^{\circ} \mathrm{C}$ e numa faixa de $\mathrm{pH}$ que variou de 7,0 a 11,0 , respectivamente. Essas enzimas foram isoladas por cromatografia líquida de alta resolução. Os ensaios enzimáticos com o substrato sintético Z-Phe-Arg-MCA e com os inibidores EGTA, EDTA e 1,10 fenantrolina indicam que essas enzimas são metaloproteases.

Palavras-chave: metaloproteases, Brevundimonas diminuta, Pseudomonadaceae, proteases extracelulares 


\section{REFERENCES}

1. Ballard, R.W.; Doudoroff. M.; Stanier, R.; Mandel, M. Taxonomy of the aerobic Pseudomonads: Pseudomonas diminuta and P. vesiculare. J. Gen. Microbiol., 53:349-361, 1968.

2. Boethling, R.S. Purification and properties of a serine protease from Pseudomonas maltophilia. J. Bacteriol., 121:933-941, 1975.

3. Bono, F.; Savi, P.; Tuong, A.; Maftouh, M.; Pereillo, J.M.; Capdevielle, J.; Guillemot, J.C.; Maffrand, J.P.; Herbert, J.M. Purification and characterization of a novel protease from culture filtrates of a Streptomyces sp. FEMS Microbiol. Lett., 141:213-220, 1996.

4. Branquinha, M.H.; Vermelho, A.B.; Goldenberg, S.; Bonaldo, M.C. Ubiquity of cysteine- and metalloproteinase activities in a wide range of trypanosomatids. J. Euk. Microbiol., 43:131-135, 1996.

5. Dumas, D.P.; Caldwell, S.R.; Wild, J.R.; Raushel, F.M. Purification and properties of the phosphotriesterase from Pseudomonas diminuta. J. Biol. Chem., 264:19659-19665, 1989.

6. Dumas, D.P.; Raushel, F.M. Chemical and kinetic evidence for an essential histidine in the phosphotriesterase from Pseudomonas diminuta. J. Biol. Chem., 265:21498-21503, 1990.

7. Heussen, C.; Dowdle, E.B. Electrophoretic analysis of plasminogen activators in polyacrylamide gels containing sodium dodecyl sulfate and copolymerized substrates. Anal. Biochem., 102:196-202, 1980.

8. Holder, I.A.; Neely, N.A. Pseudomonas Elastase Acts as a Virulence Factor in Burned Hosts by Hageman Factor-Dependent Activation of the Host Kinin Cascade. Infect. Immun., 57:3345-3348, 1989.
9. Kim, H.J.; Tamanoue, Y.; Jeohn, G.H.; Iwamatsu, A.; Yokota, A.; Kim, Y.T.; Takahadhi, T.; Takahashi, K. Purification and characterization of an extracellular metalloprotease from Pseudomonas fluorescens. J. Biol. Chem., 121:82-88, 1997.

10. Laemmli, U.K. Cleavage of structural proteins during the assembly of the head of bacteriophage T4. Nature, 227:680-685, 1970.

11. Lowry, O.H.; Rosebrough, N.J.; Farr, A.L.; Randall, R.J. Protein measurement with the Folin phenol reagent. J. Biol. Chem., 193:265-275, 1951.

12. Mizukane, R.; Hirakata, Y.; Kaku, M.; Ishii, Y.; Furuya, N.; Ishida, K.; Koga, H.; Kohno, S.; Yamaguchi, K. Comparative "in vitro"exoenzymesuppressing activities of azithromycin and other macrolide antibiotics. Antimicrob. Agents Chemother, 38:528-533, 1994.

13. Morihara, K.; Tsuzuki, H.; Oka, T. On the specificity of Pseudomonas aeruginosa alkaline proteinase with synthetic peptides. Biochim. Biophys. Acta, 309:414-429, 1973.

14. Röger, P.; Erben, A.; Lingens, F. Microbial metabolism of quinoline and related compounds. IV. Degradation of isoquinoline by Alcaligenes faecalis $\mathrm{Pa}$ and Pseudomonas diminuta 7. Biol. Chem. Hoppe-Seyler, 371:511513, 1990.

15. Segers, P.; Vancanneyt, M.; Pot, B.; Torck, U.; Hoste, B.; Dewettinck, D.; Falsen, E.; Kersters, K.; De Vos, P. Classification of Pseudomonas diminuta Leifson and Hugh 1954 and Pseudomonas vesiculares Büsing, Döll, and Freytag 1953 in Brevundimonas diminuta comb. nov. and Brevundimonas vesiculares comb. nov., respectively. Int. J. Sys. Bacteriol., 44:499-510, 1994.

16. Sexton, M.M.; Jones, A.L. Purification and characterization of a protease from Pseudomonas pseudomallei. Can. J. Microbiol., 40:903-910, 1994. 